\title{
An Analysis on Learning Condition in Developing Listening Comprehension Model by Using Social Media for English Students
}

\author{
Syofianis Ismail $^{1}$, M. Zaim ${ }^{2}$, Mukhaiyar ${ }^{3}$ and Nurhizrah Gistituati ${ }^{4}$ \\ ${ }^{1}$ Post Graduate Student of The State University of Padang, Indonesia \\ Department of English, Faculty of Education \\ email: syofianis@edu.uir.ac.id \\ ${ }^{2}$ State University of Padang \\ email: mzaim_unp@yahoo.com \\ ${ }^{3}$ State University of Padang \\ email: jmukhaiyar@yahoo.com \\ ${ }^{4}$ State University of Padang \\ email: icha_yp@yahoo.com
}

\begin{abstract}
Learning a foreign language by using social media is getting important because it has great potential to support student-centered learning, as it is flexible, interactive, and content-rich in nature. This research was aimed to develop an English listening comprehension model by using Social Media You tube. A Research and Development methodology ADDIE was used: analyzing students' and teachers' needs, designing a new learning materials, Developing material, Implementing it in a group, and evaluating the existing learning materials, validating the learning materials by experts, revising learning materials, trying out the learning materials, and revising learning materials. It was found that the existing learning materials were not appropriate for the students' characteristics and were not organized in a systematic way. Students and lecturers indicated that they appreciated enjoyable English language learning materials such as songs, stories and games using You Tube. Based on these findings a new model for developing materials was developed for English Listening Comprehension Program at the Islamic University of Riau.
\end{abstract}

Keywords: Learning material, ADDIE model, youtube.

\section{Abstrak}

Mempelajari bahasa asing dengan menggunakan media sosial menjadi penting karena memiliki potensi besar untuk mendukung pembelajaran yang berpusat pada siswa, karena bersifat fleksibel, interaktif, dan kaya konten. Penelitian ini bertujuan untuk mengembangkan model pemahaman mendengarkan bahasa Inggris dengan menggunakan tabung Social Media You. Metodologi Penelitian dan Pengembangan ADDIE digunakan: menganalisis kebutuhan siswa dan guru, merancang bahan pembelajaran baru, Mengembangkan bahan, Menerapkannya dalam kelompok, dan mengevaluasi bahan belajar 
yang ada, memvalidasi bahan belajar oleh para ahli, merevisi bahan belajar, mencoba materi pembelajaran, dan merevisi materi pembelajaran. Ditemukan bahwa materi pembelajaran yang ada tidak sesuai dengan karakteristik siswa dan tidak diorganisir secara sistematis. Mahasiswa dan dosen mengindikasikan bahwa mereka menghargai materi pembelajaran bahasa Inggris yang menyenangkan seperti lagu, cerita, dan permainan menggunakan You Tube. Berdasarkan temuan ini, model baru untuk mengembangkan bahan dikembangkan untuk Program Pemahaman Mendengarkan Bahasa Inggris di Universitas Islam Riau.

Kata Kunci: Bahan ajar, Model ADDIE, Youtube

\section{INTRODUCTION}

Listening comprehension is very important and is much needed by students in all aspects of language learning. This is because listening is one of the most important information windows apart from reading. Listening is also relatively more difficult for students to master, especially for non-English speaking learners. Furthermore, at university listening is a major skill that every English student should have in the target language. Listening skills in language learning have not received sufficient attention although forty percent of daily communication is spent on listening. Moreover, "listening remains one of the least understood processes in language learning" (Kavaliauskiene, 2011, p. 1). As "a bundle of related processes" (2002, p. 193). Rost further explains that listening is viewed as "a process involving a continuum of active processes, which are under the control of the listener, and passive processes, which are not" $(2002$, p.7). Hence, the complexity of listening is partly due to the fact that it involves a number of active and passive processes, rather than one single process. These difficulties are indicated by their low ability to understand the topic that will be analyzed, for example in determining main ideas, details of what is being listened to, including doing tasks independently or in groups. As a result the average student's score is also low, that is around 65 or $\mathrm{B}$ minus (B-). Therefore, learning listening now is shifted from developing listening skills to communication skills with the emphasis on listening and speaking.

Most of difficulties experienced by the students are limited vocabulary, unable to grasp the meaning of the speaker's pronunciation because lack of background knowledge about the topic being discussed and too fast in speaking. In addition, listening and speaking are quite difficult to practice if the children or students have never been in English-speaking countries. Based on the background above, the goals of this research are:

1. To analyze the conditions and learning needs for English students of listening comprehension at the English Language Study Program FKIP Riau Islamic University.

2. To design, develop and implement the model of learning listening comprehension for students of English listening comprehension at the English Study Program by using social media. 


\section{METHOD}

The samples for this study were taken from population of the English Language Education (ELE) Students, the Faculty of Teacher Training and Education in the Islamic University of Riau. There are 152 students in 4 classes who were taking courses in listening comprehension in the first semester of 2018. From these 4 classes, 10 students were taken as samples from each class by using simple random sampling, so that the number of respondents were 40 students or $26 \%$ of the total population. The reason for using a simple random method is because the population is considered relatively homogeneous. We also conducted the validity and the reliability test on this collected data and the results do not violate the statistical rules.

Required data for this research consists of qualitative and quantitative data. The qualitative data include data relating to the characteristics or personal profile data of students such as name, age, hobbies, students' perceptions, competence towards listening learning process, grammar, ability to use computer and IT devices, student and other listening learning needs- other. The quantitative required are students' marks.

We run the pre-test to get the score of the students before the treatment of listening. For the post-test, we run the treatment, that is the students are listening to the lesson test. After listening to the listening test, the students are then asked several questions related to the story that just been listened by the them These questions are about Comprehension questions, which consist of multiple choice questions, True False etc. are called as post-test. The differences of results between pre and post-test can be mainly attributed to the treatment that given to the students. These process are repeated several time in order to get reliable data.

\section{RESULT AND DISCUSSION}

As stated previously the goals of this research are two folds, firstly, to analyze the condition of learning process and the learning needs of the students' listening comprehension, and secondly, to design, develop and implement the model of listening comprehension for students at the English Language Study Program by using social media (Luxin, G, 2018).

The learning condition of the students' of Islamic University of Riau, especially at English Language Education , is still unsatisfactory. From the evaluation conducted by the Language Institute of the Islamic University of Riau, the mastery of the students are still below the expectations. On average, their TOEFL score is only around 400 to 450 . TOEFL prediction test as a Final Assignment (TA) requirement, show that the 'listening comprehension' scores were only around $46 \%$. Most of the difficulties experienced by the students are limited vocabulary, unable to grasp the meaning of the speaker's pronunciation because of a lack of background knowledge about the topic being discussed and too fast in speaking. To overcome this problem we have designed a suitable learning process by using ADDIE model.

As the figure described below: 


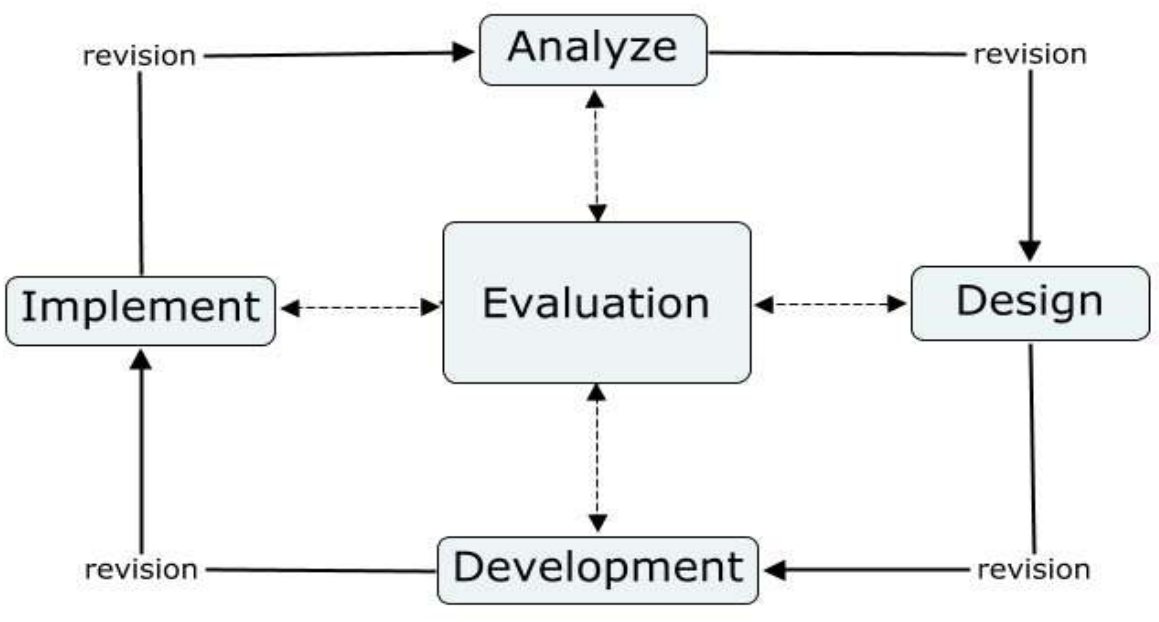

Figure 1. ADDIE Model: 2009.

To achieve the first research goal we did a survey to the students in order to know their current conditions and their need related to listening comprehension. Based on their answer we got the results as follow. First, majority of the students (54\%) agree with the use of social media as medium of learning process, particularly for listening. Secondly, there are $25 \%$ of the students who very agree with the use of social media. This means that majority $(79 \%)$ of the students agree with the use social media as medium of learning listening. There are only $7 \%$ of students who do not agree and $14 \%$ who less agree with the use of social media as medium of listening learning. It indicates that there are roughly $21 \%$ of the students who are not interested in using social media as medium of learning, Darmansyah. (2010). These small number of students who do not agree with, need to be further investigated why they have such an opinion in the middle of the wave of information technology. In the future there are two groups of students eventually will be forced naturally to use the information technology as the coming wave of technology is something unavoidable. Almost all the government services will be delivered by using internet or information technology, let alone the business and other private services.

The following activities on analysis stage are identifying lectures' problems, students' problems and identifying problems related to instructional. The instrument used to obtain the lectures problems were interviewed and observation. The general interview questions based on rubric such as problems, teaching listening, media, strategy, learning resources, evaluation, achievement and solution. There are two lectures were interviewed, A and B. The interview was conducted deal with the teaching listening process, media, learning resources, classroom management, evaluation on students' achievement and solution to the problems. Prior to interview and observation the instrument were validated by some experts. The results of validation 
indicated that all the instruments were valid and reliable therefore, the instrument can be used to obtain the data. Based on the interview and observation, it can be concluded that there are several problems related to listening. Firstly, most of the students had difficulties in listening.

Table 1. Activities in Analysis Stage.

\begin{tabular}{|c|c|c|}
\hline No & Activities & Technique \\
\hline 1 & $\begin{array}{l}\text { Identifying } \\
\text { lecturer } \\
\text { problems }\end{array}$ & $\begin{array}{l}\text { Need } \\
\text { Analysis }\end{array}$ \\
\hline 2 & $\begin{array}{l}\text { Identifying } \\
\text { students } \\
\text { problems }\end{array}$ & $\begin{array}{l}\text { Learner } \\
\text { analysis }\end{array}$ \\
\hline 3 & $\begin{array}{l}\text { Identifying } \\
\text { problems } \\
\text { related to } \\
\text { instructional } \\
\text { material }\end{array}$ & $\begin{array}{l}\text { Task } \\
\text { Analysis } \\
\text { Specifying } \\
\text { Goal } \\
\text { Criterion } \\
\text { Reference } \\
\text { Test }\end{array}$ \\
\hline
\end{tabular}

\section{Lecturer' Problems}

There are two lectures interviewed, they are identified by name as lecturer A and lecturer B. Lecturer A said that about 50 to $55 \%$ of their students are having difficulties when they were listening to the audio in the classroom. These difficulties arise because they are not familiar with the pronunciation, time allocation is too short, the materials are difficult and vocabulary is limited. The students were usually missed the first or the second questions because they are unaware of the starting time of listening to audio.

Lecturer B explained that there are several factors which cause the students have difficulties in listening. These factors are the limited amount of time available, unfamiliar with materials and others. Lecturer A also share what Lecture B said about what makes the students have difficulties in listening. The Lecturers said, "in the lectures' opinion the students are not familiar with and accustom to the listening material." These factors make them reluctant to listen regularly." This information is also supported by lecturer B who also confirms that listening is difficult for the students because they do not spend enough time in the listening exercise.

Other than the limited amount of time spent on listening exercise, the students' language ability, such as vocabulary, also appear as problems in listening. When the vocabulary is limited the students do not have enough words in their mind so that they cannot make association on one word to another.

Teachers or lectures are another important factors that contribute to the students' difficulties in listening. If the pronunciation of teachers or lecturers are not clear and good enough, according to the minimal requirement, then the students' listening will be below the standard of the teachers. This is because the students will imitate their teacher's pronunciation. When they do not pronounce some words correctly then the students will also do the same. As the information technology become more available the problems can be solved by using online recorded material.

Another important difficulties in listening is motivation (Guan, 2019). Motivation is very important factor that 
push students to uplift themselves into higher ladder of their life. Students with high motivation will do whatever they can possibly do.

Design of the Instructional Listening Comprehension Social Media Based (LCSMB) is a model guideline for teaching listening to help lecturers develop English listening lessons, enhance learning listening and encourage the engagement of students. The LCSMB model is a systematic, web-based instruction using interactive task-based approach. This model consists of 5 phases and 17 steps of ADDIE model (Branch, 2009). Before the instructional process is designed, it is necessary to identify the background and problems of English listening instruction. These phases are the base of the whole instructional process.

The analysis used to help create and develop the listening product is ADDIE process. The ADDIE process consists of five stages (Branch, 2009), namely: analysis, design, development, implementation and evaluation. The analysis phase is a process of defining what will be learned by students / learners by conducting a needs analysis, identifying problems, and performing task analysis (Gu, 2018). The output of task analysis is the characteristics of student profiles, identification of gaps, identification of needs and analysis of appropriate tasks that are detailed based on the needs. The next stage is design or blue print to formulate the learning objectives, compile tests and to determine the right learning strategies to achieve these goals. The development phase is the process of realizing blue-print or design into reality. The design itself requires expert validation which will be realized in the product revision. The implementation phase is a real step to implement the learning model that is being made, meaning that everything that has been developed is applied in the form of model application. The last stage of ADDIE, evaluation phase, is a process to see whether the learning model is made in accordance with initial expectations or not. In the following a picture of a research framework for developing Listening Comprehension will be elaborated.

\section{Needs Analysis}

Need analysis is aimed to identify the problems and the needs of the learners of English listening. The findings obtained from this analysis can contribute to the setting instructional goals and learning objectives and can help instructors draw the main components and requirements of LCSMB.

\section{Analyze Existing Curriculum}

It is important to analyze the existing curriculum and syllabus thoroughly because they play an important role as a defined and prescribed course of studies. Instructors should pay attention on analyzing the requirements and the expected output of the listening skills based on the existing curriculum.

\section{Identify Learning Context}

Analysis is focused on the technical environment and instructional structure. For the technical environment, instructors should concern about organizing minimum requirements such as computers, the Internet, the Intranet, network servers, server capabilities, software, and hardware. For instructional structure, instructors should focus on teaching methodology to fit English listening instruction. 


\section{Analyze Instructional Content}

Instructor would analyze the domain (type) and sequence (level) of the LSCMB contents. A content domain analysis identifies whether the main purpose of instructional content is to change the learners' cognitive, emotional, or physical status, while a content level analysis determines the optimal range of the sequence of learning required for achieving the instructional goal (Chyung \& Trenas, 2009).

\section{Set Instructional Goals and Teaching Goals}

Instructor needs to specify what the learners will be able to do when they complete the instruction. The goals should be clear, concise, complete and manageable. The goals are about what the instructor plans to teach, what instructors will cover in this course and how instructors will cover it. These goals are usually broad, and vague depending on different learners.

\section{Set Learning Goals}

Learning goals describe what exactly the instructors expect learners will learn. The goals involve enabling objectives and terminal objectives.

\section{Design Lessons}

Instructors should outline how to achieve the instructional goals. Attention should be given to the effectiveness of lesson elements and criteria for designing assessment.

\section{Manage Content}

Authentic resources for the instruction, which are found in books, online or in other media, are required to support English listening instruction and learners.

\section{Determine Instructional Strategies}

Based on learning objectives, instructors are required to determine appropriate instructional strategies to maximize learning effectiveness. Based on the nature of listening comprehension and the features of listening instruction, the LCSMB Model will focuses on interactive instruction.

\section{Establish Listening Tasks}

The tasks in the LCSMB lessons will be designed to real-world tasks according to the TBA principles.

\section{Design Testing}

Task-based assessment should be used in the LCSMB Model. Instructor needs to create the criteria and format of testing. The assessment should provide learners feedback and remediation when necessary.

\section{Produce Online Instructional Package}

Instructors should decide what software or online tools will be used as an instructional platform or tools to deliver the lessons according to the learning context analysis.

\section{Select Modules}

Software company usually offers the instructor modules or tools to create a course website and provide access control. According to the instructional goals, the modules which include "Forum, Glossary, Chat, Wiki and Quiz" can be chosen to deliver the instruction.

\section{Integrate Media}

Media for online instruction includes text, images/graphics, audio, video, games, and e-books. All media should be optimized to match the minimum requirements of the available hardware 
for the LSCMB instruction and be delivered effectively for improving listening ability.

\section{Prototype Lessons}

The LCSMB lesson template should be interactive and flexible. The prototype will be formatively evaluated to check whether it serves the instructional goals.

\section{Conduct Developed lessons}

The teaching process should emphasize learner-centered learning and learning in interaction. Implement Computer-mediated Interaction Computer-mediated interaction allows learners to communicate with other learners in both asynchronous and synchronous modes by network and permits one-to-one and one-to-many communication.

\section{Encourage Peer Face-to-face Interaction}

Peer face-to-face interaction should be managed in LCSMB, focusing on the learning process by encouraging interaction among students.

\section{Evaluation}

Evaluation should be used to evaluate learning processes and outcomes.

\section{Conduct Formative Evaluation}

Formative evaluation is presented in each stage of the LSCMB Model. It provides the information for ongoing improvement and adjustment.

\section{Conduct Summative Evaluation}

At the end of the course, a summative post-test will be carried out to obtain the data to evaluate the effectiveness of teaching and learning process. To sum up, LCSMB Model is an online interactive listening instruction designed with task-based approach. As a systemoriented model, each step is critical and need to be completed. Instructional strategies in the LCSMB Model rely on interaction and cooperative learning with real-world tasks. Additionally, the LCSMB Model is a learner-centered instruction design, emphasizing on interaction.

\section{CONCLUSIONS}

The current study has been conducted in order to solve an important issue of students listening comprehension ability articulated in the establishment a social media-based listening teaching model and deliver listening courses via the intranet or campus network. The objectives of the study were to develop an online listening instructional model for English Study Program learners, and to investigate the effects of using LCSMB model. The findings revealed that the LCSMB Model was suitable to teach English listening online with task-based approach, emphasizing interaction, activity and flexibility. The LCSMB brings broad changes to the traditional way of teaching listening skills in English and the relationships between teachers and students. Students could learn English listening anytime and anywhere through LCSMB. For pedagogical implication, the development of the LCSMB Model might offer practical solutions for the development of English teaching and improve students' listening ability at the Islamic University of Riau. 


\section{ACKNOWLEDGEMENTS}

I would like to thank all those who took part in this research project. I am also grateful to the following scholars and friends who have offered me tremendous help and support in reporting of this research journal: Prof. M. Zaim, Prof. Mukhaiyar, Dr. Suardi Tarumun, Prof. Nurhizrah Gistituati and Dr, Sri Yuliani, Prof. Seno H. Putra and all my students who involved in this research.

\section{REFERENCES}

Anderson, T. (2008) The theory and practice of online learning (2nd ed.). Edmonton, AB: Athabasca University (AU) Press.

Ansyar, M. (2016). Kurikulum: Hakikat, Fondasi, Desain \& Pengembangan. Jakarta: Kencana.

Barhoumi \& Rossi. (2013). The Effectiveness of WhatsApp Mobile Learning Activities Guided by Activity Theory on Students' Knowledge Management. Contemporary Educational Technology, 2015, 6(3), 221-238.

Branch, Rober M. (2009). Instructional Design: The ADDIE Approach. New York: Springer

Cross, Jeremy. (2011). Comprehending news videotext: the influence of visual content volume 15. Nanyang technological University Press.
Chyung, S.Y. \& Treñas, A.S

(2009). Content Analysis: Key to

Excellence in Your Blended

Learning, Inc. Boise State

University Fellow

Darmansyah. (2010). Pembelajaran Berbasis Web: Teori, konsep dan Aplikasi. Padang: UNP Press.

Eren, O. (2012). Students' Attitudes towards Using Social Networking in Foreign Language Classes: A Facebook Example. International Journal of Business and Social Science, vol 3 no 20, October 2012.

Gu Luxin. (2018). A Review of the

Theories and Principles of

Teaching Listening and Their

Guidance in Senior High English

Lessons Studies in English

Language Teaching ISSN 2372-

9740 (Print) ISSN 2329-311X

(Online) Vol. 6, No. 1, 2018

www.scholink.org/ojs/index.php/s

elt.

Guan. Yi. (2015). Current Issues in Listening Strategy Research and Instruction on ESL Adult Learners International Journal of Teaching, Education and Language Learning (IJTELL) January 2015, Vol.2, No.1, pp.3270 .

Hopkin, B. (2017). Advantages of Using Social Media for Students in Education. 
https://www.academiaapps.com/a

dvantages-social-media-

education/

Ismail, S. (2016). The Effect of TV News Video towards Students' Listening Comprehension of The first year Students of SMAN 2 Tambang, Riau, Indonesia. The $15^{\text {th }}$ Asia Call, Xian, China.

Ismail, S., Marhamah A. (2015). Pengaruh Podcast Terhadap Pemahaman Mendengarkan Dari Mahasiswa Semester Dua Program Studi Bahasa Inggris di Universitas Islam Riau.

Ismail, S., Rizqiani, A., \& Meika. (2014). The Effect Using Facebook as a Medium for Discussion to Improve Students' Writing ability of Recount Text of the First Year Students at SMAN 5 Pekanbaru, Indonesia. Proceedings of the 2014 ASIA CALL Conference. National Changhua University, Taiwan: ASIACALL.

John, Abi Mathew. (2017). "Student attitudes on social media and perception of instructor social media use." Electronic Theses and Dissertations. Paper 2647. https://doi.org/10.18297/etd/2647

Nadzrah, A. B., \& Mickan, P. (2003). Students' experiences in computer-based English language classroom. Proceedings of the 2003 ASIA CALL Conference.
Gyeongju University, South Korea: ASIACALL

Kavaliauskiene, G. (2011). Blended Learning In ESP Listening. English for Specific Purposes Worldjournal, 31 (10), 201. Mykolas Romeris University, Vilnius, Lithuania

Nunan, D. 2001. English as global language. Tesol Quarterly, Volume 32, Issue 4. ISSN: 15457249.

Rajesh, S., Jithin M. (2015). Effectiveness of Social Media in Education. International Journal of Innovative Research in Advanced Engineering (IJIRAE) ISSN: 2349-2163 Issue 10, Volume 2 (October 2015). 